\title{
A fast stratospheric chemistry solver: the E4CHEM submodel for the atmospheric chemistry global circulation model EMAC
}

\author{
A. J. G. Baumgaertner ${ }^{1}$, P. Jöckel ${ }^{1,{ }^{*}}$, B. Steil ${ }^{1}$, H. Tost ${ }^{1}$, and R. Sander ${ }^{1}$ \\ ${ }^{1}$ Max Planck Institute for Chemistry, 55020 Mainz, Germany \\ *now at: Deutsches Zentrum für Luft- und Raumfahrt (DLR), Institut für Physik der Atmosphäre, Oberpfaffenhofen, \\ 82234 Weßling, Germany
}

Received: 2 February 2010 - Published in Geosci. Model Dev. Discuss.: 17 February 2010

Revised: 21 May 2010 - Accepted: 4 June 2010 - Published: 22 June 2010

\begin{abstract}
The atmospheric chemistry general circulation model ECHAM5/MESSy (EMAC) and the atmospheric chemistry box model CAABA are extended by a computationally very efficient submodel for atmospheric chemistry, E4CHEM. It focuses on stratospheric chemistry but also includes background tropospheric chemistry. It is based on the chemistry of MAECHAM4-CHEM and is intended to serve as a simple and fast alternative to the flexible but also computationally more demanding submodel MECCA. In a model setup with E4CHEM, EMAC is now also suitable for simulations of longer time scales. The reaction mechanism contains basic $\mathrm{O}_{3}, \mathrm{CH}_{4}, \mathrm{CO}, \mathrm{HO}_{\mathrm{x}}, \mathrm{NO}_{\mathrm{x}}$, and $\mathrm{ClO}_{\mathrm{x}}$ gas phase chemistry. In addition, E4CHEM includes optional fast routines for heterogeneous reactions on sulphate aerosols and polar stratospheric clouds (substituting the existing submodels PSC and HETCHEM), and scavenging (substituting the existing submodel SCAV). We describe the implementation of E4CHEM into the MESSy structure of CAABA and EMAC. For some species the steady state in the box model differs by up to $100 \%$ when compared to results from CAABA/MECCA due to different reaction rates. After an update of the reaction rates in E4CHEM the mixing ratios in both boxmodel and 3-D model simulations are in satisfactory agreement with the results from a simulation where MECCA with a similar chemistry scheme was employed. Finally, a comparison against a simulation with a more complex and already evaluated chemical mechanism is presented in order to discuss shortcomings associated with the simplification of the chemical mechanism.
\end{abstract}

Correspondence to:

A. J. G. Baumgaertner

(work@andreas-baumgaertner.net)

\section{Introduction}

In an attempt to better understand atmospheric chemistry and the atmosphere as a whole, in the last decade atmospheric models have been extended by routines accounting for chemical reactions in the atmosphere. Today, a variety of implementations of algorithms which numerically solve the coupled differential equations that describe the chemical reactions important in the atmosphere exist. Many chemistry climate models that include the stratosphere participate in the validation study CCMVal by the SPARC (Stratospheric Processes and their Role in Climate, Eyring et al., 2010) project of WCRP. Such models and their performance have been reviewed and validated by e.g. Austin et al. (2003); Eyring et al. (2006, 2007); Austin et al. (2008); Austin et al. (2010).

The atmospheric chemistry general circulation model ECHAM5/MESSy (EMAC) already contains the very flexible chemistry module MECCA (Sander et al., 2005), which is also part of the boxmodel CAABA (Sander et al., 2010); the two models form a consistent model hierarchy (see also Riede et al., 2009). MECCA, which utilises the Kinetic PreProcessor (KPP, Sandu and Sander, 2006), is routinely used for simulations from the surface to the mesosphere (e.g. Jöckel et al., 2006). Here, we describe the implementation of the fast chemical submodel E4CHEM, which is based on the widely used CHEM subroutine available for ECHAM4. The submodel is, according to the MESSy plug\&play approach, available as a box model process for CAABA as well as for the 3-D model EMAC (Sect. 2).

By comparing simulation results using E4CHEM with simulations that employ MECCA, we show that during the transition the algorithms are not deteriorated and that the results of the new system are in sufficient agreement with the alternative, more complex approach of MECCA (Sect. 3). We argue that EMAC simulations with E4CHEM can be

Published by Copernicus Publications on behalf of the European Geosciences Union. 
performed for many decades and are thus useful for climate simulations, where the feedback of radiatively active gases such as ozone is of particular interest (Sect. 4).

\section{Model description}

The bases for the E4CHEM submodel were the chemical scheme and solver contained in the CHEM subroutine of ECHAM3/4-CHEM, introduced by Steil et al. (1998). In the ECHAM3/4 implementations the subroutine CHEM has been used extensively, results are for example presented by Hein et al. (2001), Steil et al. (2003), Manzini et al. (2003), Lemmen et al. (2006), Dameris et al. (2005), and Grewe (2007). The solver has been described in detail by Steil et al. (1998), therefore we will only summarize the employed technique here.

The chemistry module focuses on stratospheric ozone chemistry but also includes tropospheric background $\mathrm{NO}_{\mathrm{x}}-$ $\mathrm{HO}_{\mathrm{x}}-\mathrm{CH}_{4}-\mathrm{CO}-\mathrm{O}_{3}$ chemistry. In addition to the gas phase chemistry, E4CHEM also accounts for heterogeneous chemistry on polar stratospheric clouds and sulfate aerosol and contains its own PSC-scheme (types I and II PSCs, see Steil et al., 1998). It considers 110 photochemical reactions of 38 species: $\mathrm{N}_{2} \mathrm{O}, \mathrm{CH}_{4}, \mathrm{H}_{2}, \mathrm{H}_{2} \mathrm{O}, \mathrm{CO}_{2}, \mathrm{CO}, \mathrm{CH}_{3} \mathrm{O}_{2} \mathrm{H}$, $\mathrm{HCHO}, \mathrm{CH}_{3} \mathrm{O}_{2}, \mathrm{CH}_{3} \mathrm{O}, \mathrm{HO}_{\mathrm{x}}\left(=\mathrm{H}+\mathrm{OH}+\mathrm{HO}_{2}\right), \mathrm{H}_{2} \mathrm{O}_{2}, \mathrm{NO}_{\mathrm{x}}$ $\left(=\mathrm{N}+\mathrm{NO}+\mathrm{NO}_{2}+\mathrm{NO}_{3}+\mathrm{HNO}_{4}+2 \cdot \mathrm{N}_{2} \mathrm{O}_{5}\right), \mathrm{HNO}_{3}, \mathrm{HCl}$, $\mathrm{ClONO}_{2}, \mathrm{CFC11}, \mathrm{CFC12}, \mathrm{CH}_{3} \mathrm{Cl}, \mathrm{CH}_{3} \mathrm{CCl}_{3}, \mathrm{CCl}_{4}, \mathrm{ClO}_{\mathrm{x}}(=$ $\left.\mathrm{Cl}+\mathrm{ClO}+\mathrm{HOCl}+2 \cdot \mathrm{Cl}_{2} \mathrm{O}_{2},+2 \cdot \mathrm{Cl}_{2}\right), \mathrm{O}_{\mathrm{x}}\left(=\mathrm{O}_{3}+\mathrm{O}\left({ }^{3} \mathrm{P}\right)\right.$ $\left.+\mathrm{O}\left({ }^{1} \mathrm{D}\right)\right)$, type I PSC(NAT), and type II PSC(ice). The results of the experimental study of Hanson and Mauersberger (1988) are applied to determine when PSCs are thermodynamically possible, based on the simulated temperature and the mixing ratios of $\mathrm{HNO}_{3}$ and $\mathrm{H}_{2} \mathrm{O}$. It is assumed that ice forms on large NAT particles. The sedimentation velocity of NAT and ice is considered to be identical if ice is present, otherwise sedimentation is neglected. The stokes velocity of ice particles is calculated every timestep according to the changing radius due to condensation or evaporation of water vapour. This scheme may underestimate denitrification in the Arctic but is well suitable for the Antarctic lower stratosphere where ice particles occur frequently. In general, the numerical methods used to integrate the chemical system are semiimplicit, positive definite and mass conserving. The numerics are based on an advanced family concept. The prognostic equations are integrated using a semi-analytic exponential approach or Eulerian backward. There are three major changes compared to the standard family approach. Firstly, not only the steady state approach is used to partition the families, but depending on the lifetime of the species also the Eulerian backward and the Exponential method. Secondly, to partly overcome the process splitting problem in the family approach (i.e. the fixed order in integrating the families which can cause instabilities if a too strong coupling between families exists), a combined "super-family" for nitrate and chlorine containing species has been introduced to account for the strong coupling, especially in the case of heterogeneous chemistry on PSCs. Lastly, the definition of families for transport and chemistry does not necessarily coincide, e.g. chlorine nitrate $\left(\mathrm{ClONO}_{2}\right)$ is transported separately but included in the $\mathrm{NO}_{\mathrm{x}}-\mathrm{ClO}_{\mathrm{x}}$ - super-family. To further improve the numerical efficiency, E4CHEM has a special reduced nighttime chemistry. The numerics of E4CHEM provides two considerable advantages. The accuracy of the integration shows just a weak dependence on the length of the timestep. This allows decoupling of the chemistry timestep from the timestep of the hosting model, i.e. E4CHEM can easily be called at a multiple of the GCM-timestep (a feature that has not been applied for the simulations of this paper). This makes E4CHEM attractive for the use in high resolution models with short time steps. Essentially, the cost for the chemistry integration itself can be neglected and just the additional overhead caused by the transport of species remains. Furthermore, the numerics of E4CHEM provide a well defined, good-natured error behaviour. The chosen numerical methods ensure that in the case of a numerical error the system moves towards chemical steady-state. This stability characteristic is especially favourable in long-term integrations.

While a comparison with state of the art chemistry modules requires an update of the employed reaction rates, an evaluation against published results that employed the CHEM subroutine is only possible with the original rates. Therefore, the new reaction rates were implemented as an alternative that can be selected at compile time. The new reaction rates were taken to be the same as in MECCA, see Sander et al. (2010) for references to the individual reaction rate studies. Some differences to the MECCA mechanism in the hydrocarbon chemistry remain, so a perfect agreement cannot be expected. Note also that the photolysis rates in EMAC and CAABA are calculated by the submodel JVAL (based on Landgraf and Crutzen, 1998), so there will be differences to the results of previous studies with CHEM even if the original reaction rates are used.

In order to comply with the MESSy standard (Jöckel et al., 2005), the code was completely converted from FORTRAN77 to Fortran 90/95. As required by MESSy, the solver is located in the submodel core layer and called from the submodel interface layers, currently either an ECHAM5 interface, or a CAABA box model interface.

Note that because of the widespread usage of CHEM, a number of often undocumented extensions exist. This includes for example the consideration of type Ib (STS) sulfatebased PSC, a chemical budget analysis, or a parametrised bromine-catalyzed ozone loss as implemented by Stenke et al. (2009) for more realistic ozonehole simulations. The latter extension is optionally available for E4CHEM (via a namelist switch). Here, we use CHEM in a state as close as possible to the state evaluated in Steil et al. (1998) and therefore do not use any of the more recently developed extensions. 


\subsection{Implementation in the boxmodel CAABA}

CAABA (Sander et al., 2010) is an atmospheric chemistry box model which uses MESSy to couple the individual processes. E4CHEM was integrated as an alternative solver in CAABA, where it can replace the gas phase chemistry submodel MECCA. Like MECCA, it uses JVAL to obtain photolysis rates.

\subsection{Implementation in the 3-D model EMAC}

In the 3-D model EMAC, E4CHEM can be used as an alternative to MECCA, similar to the integration into CAABA. Note that CAABA and EMAC use identical submodel core layer files, only the interface layer differs. The interface of E4CHEM to the basemodel ECHAM5 in EMAC is very similar to the respective interface of MECCA. It contains:

- the call to the initialisation subroutines, such as the precalculation of temperature dependent reaction rates and the stratospheric sulphuric acid aerosol surface areas;

- the coupling to other submodels. In the standard setting the photolysis rates are taken from the submodel JVAL, the tropopause height is taken from the submodel TROPOP. If E4CHEM is also used for scavenging calculations, then it couples also to CLOUD, CVTRANS, and CONVECT;

- the coupling to the MESSy submodel TRACER (Jöckel et al., 2008), which is used to create and manage the tracers. This also allows to easily define tracer families (via the corresponding namelist) for advection;

- the call to the solver subroutine CHEM which resides in the core layer.

The submodels PSC and HETCHEM, needed for EMAC simulations with MECCA, can be switched off if E4CHEM is used, since E4CHEM already contains heterogeneous chemistry on sulphate aerosols and polar stratospheric clouds.

\section{Model evaluation}

\subsection{E4CHEM in the box model CAABA}

The box model version of the solver and chemistry of E4CHEM has been evaluated by comparison to the quasiexact scheme of FACSIMILE in Steil (1997) and we restrict the evaluation here to a comparison with MECCA.

The here applied MECCA mechanism, which is equivalent to the E4CHEM chemistry, contains the reactions labelled for the stratosphere, however, bromine, iodine and mercury containing reactions have to be excluded.
Figure 1 depicts selected box model results from simulations with CAABA employing MECCA (black lines) and E4CHEM using the original (red) and updated (green) reaction rates. The simulations were performed for mid-latitude $\left(45^{\circ} \mathrm{N}\right)$ summer ( $\left.1 \mathrm{July}-8 \mathrm{July}\right)$, at $10 \mathrm{hPa}$. The chemistry was initialised using the results from a 3-D simulation with EMAC. A time step of 20 min was selected.

There is a good agreement for $\mathrm{NO}, \mathrm{NO}_{2}, \mathrm{~N}_{2} \mathrm{O}_{5}, \mathrm{HNO}_{3}$, $\mathrm{OH}, \mathrm{HO}_{2}, \mathrm{HCHO}$ and ozone in all simulations. However, large discrepancies are found for $\mathrm{HNO}_{4}, \mathrm{H}_{2} \mathrm{O}_{2}$, and $\mathrm{H}$ between the E4CHEM simulation with the original reaction rates and the other two simulations. For $\mathrm{CH}_{3} \mathrm{OOH}$ the difference between MECCA and E4CHEM with new reaction rates is smaller by $50 \%$ when compared to E4CHEM with the old reaction rates, but still amounts to approximately $20 \%$. This is likely due to the differences between E4CHEM and MECCA in the hydrocarbon mechanism as mentioned above. The supplement contains a comparison for all chemical species contained in E4CHEM.

The CPU time consumed by the CAABA simulations with the photolysis submodel JVAL and E4CHEM or MECCA switched on was measured on an IBM POWER6 architecture using simulation lengths of 20 days. The E4CHEM simulation required $1.29 \mathrm{~s}$ and the MECCA simulation $1.40 \mathrm{~s}$, thus the speedup-factor is 1.09 . However, a simulation with both chemistry submodels turned off and only the photolysis submodel JVAL turned on required $1.15 \mathrm{~s}$. Therefore, much of the performance increase is concealed by JVAL and other parts of CAABA. The computing time of the chemistry submodels only is estimated from the differences of the simulations with chemistry and the JVAL-only simulation, yielding $0.25 \mathrm{~s}$ for MECCA and $0.14 \mathrm{~s}$ for E4CHEM, which gives a speedup-factor of 1.79. In the CAABA box model, the submodel JVAL calculates the photolysis rates of all implemented species, many more than required by the chemical mechanisms employed here. This leads to the large resource demand compared to the chemistry submodels, which is generally not relevant due to the low resource demand of the box model. Note that in the 3-D EMAC model (see Sect. 3.2), the JVAL interface is optimised such that JVAL calculates only the photolysis rates of species actually contained in the employed chemical mechanism.

\subsection{E4CHEM in the EMAC 3-D model}

As mentioned above, the chemical scheme of E4CHEM has been tested and used extensively in chemistry climate models. In order to evaluate E4CHEM in the EMAC model system, we compare three simulations, the first using E4CHEM, the other two using MECCA. The differences between the simulations are summarised in Table 1. All simulations were carried out for the year 1998 with a spectral truncation of $\mathrm{T} 42$, corresponding to a horizontal resolution of approximately $2.8^{\circ} \times 2.8^{\circ}$, and 90 layers in the vertical (L90MA) reaching up to $0.01 \mathrm{hPa}$. Other submodels that were switched 

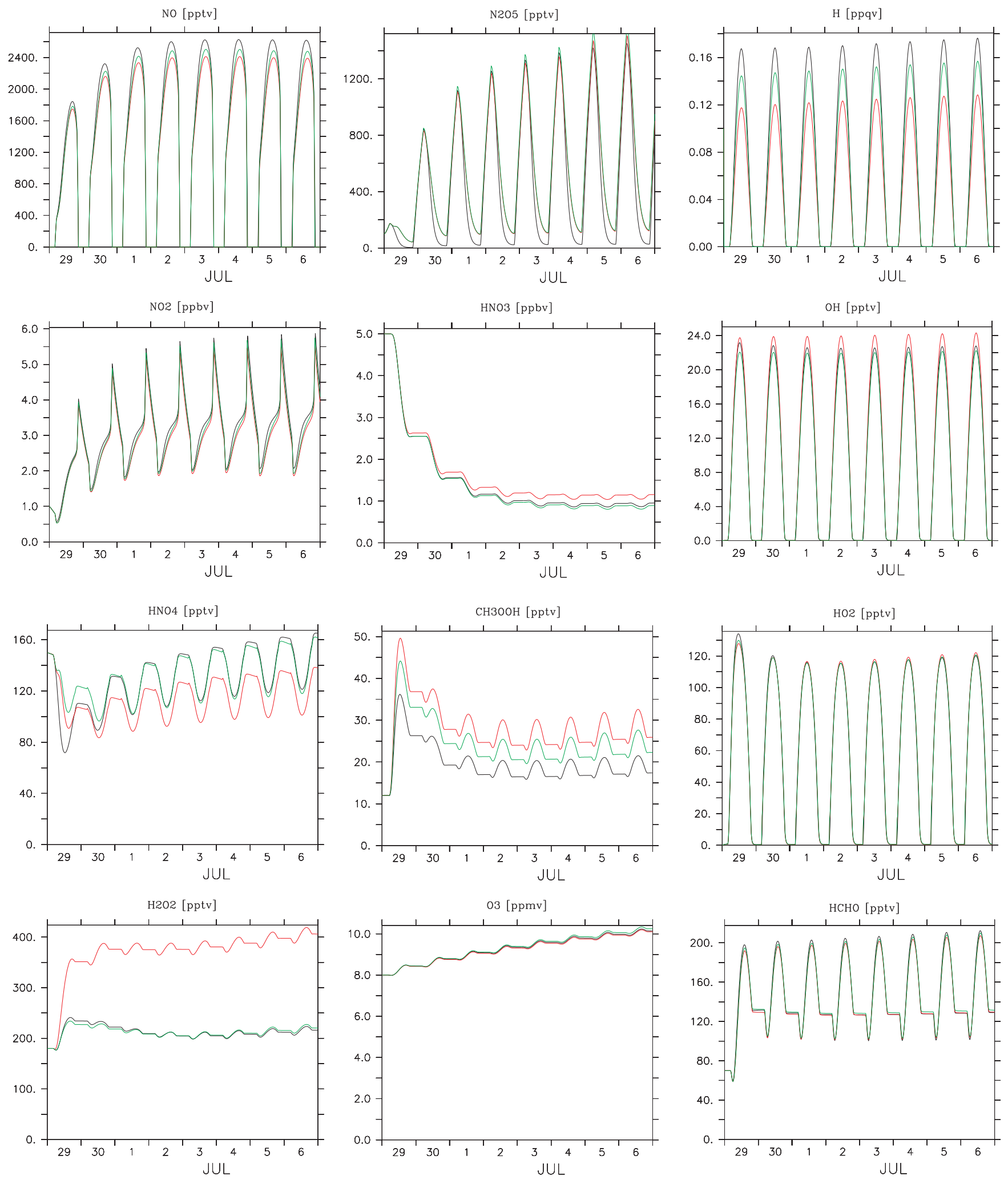

Fig. 1. CAABA box model simulation results with MECCA (black), E4CHEM with original rates (red), and E4CHEM with updated rates (green) for selected species. 
Table 1. Overview of the performed EMAC simulations.

\begin{tabular}{llll}
\hline Simulation & S-E4CHEM & S-MECCA(E4CHEM) & S-MECCA(EVAL) \\
\hline Chemistry submodel & E4CHEM & $\begin{array}{l}\text { MECCA, selected mechanism } \\
\text { similar to E4CHEM }\end{array}$ & $\begin{array}{l}\text { MECCA, mechanism from } \\
\text { evaluation study } \\
\text { Tracer families for transport }\end{array}$ \\
$\begin{array}{lll}\mathrm{NO}_{\mathrm{x}}, \mathrm{ClO}_{\mathrm{x}}, \mathrm{O}_{\mathrm{x}}, \mathrm{HNO}_{3}+\mathrm{NAT} \\
\mathrm{NO}_{\mathrm{x}}, \mathrm{ClO}_{\mathrm{x}}, \mathrm{O}_{\mathrm{x}}\end{array}$ & $\begin{array}{l}\text { simplified scavenging } \\
\text { Scavenging (see Tost et al., 2006a) }\end{array}$ & $\begin{array}{l}\text { simplified scavenging } \\
\text { (effective Henry's law; pH 5) }\end{array}$ & $\begin{array}{l}\text { (effective Henry's law; pH 5) } \\
\text { evaluation study by Jöckel et al. (2006) }\end{array}$
\end{tabular}

Heterogenous chemistry and

accounted for in E4CHEM core

submodels HETCHEM and PSC

submodels HETCHEM and PSC polar stratospheric clouds
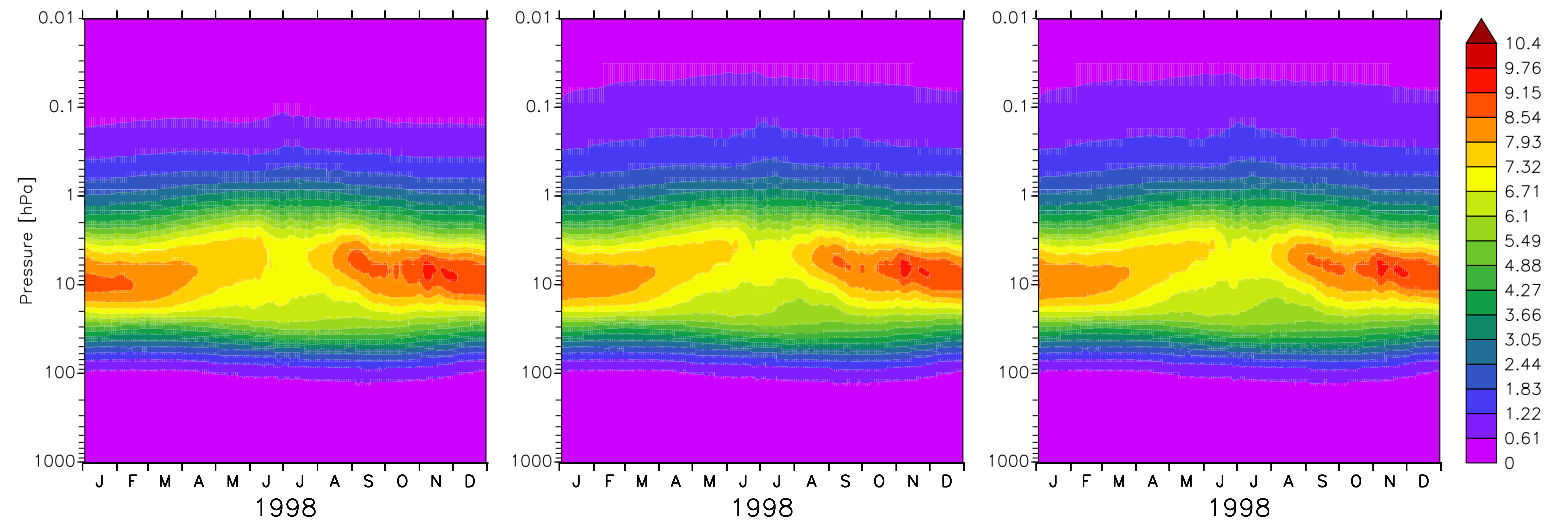

Fig. 2. EMAC ozone ( $\mu \mathrm{mol} / \mathrm{mol})$ from simulations with S-E4CHEM (left), S-MECCA(E4CHEM) (middle) and S-MECCA(EVAL) (right) for the zonal average at $30^{\circ} \mathrm{S}-50^{\circ} \mathrm{S}$.

on in all simulations are CLOUD (cloud routines), CONVECT (convection parametrisation, see Tost et al., 2006b), CVTRANS (convective tracer transport), DRYDEP (dry deposition, see Kerkweg et al., 2006a), $\mathrm{H}_{2} \mathrm{O}$ (consistent feedback of the chemical tracer water vapour with specific humidity of the base model), JVAL (based on Landgraf and Crutzen, 1998), LNOX (a lightning $\mathrm{NO}_{\mathrm{x}}$ parametrisation, see Tost et al., 2007), OFFLEM (offline emission of trace gases, see Kerkweg et al., 2006b), ONLEM (online calculated emission of trace gases, see Kerkweg et al., 2006b), QBO (assimilation of QBO zonal wind observations), RAD4ALL (radiation code), SCAV (scavenging parametrisation by Tost et al., 2006a), TNUDGE (Newtonian relaxation of long-lived trace gases at the surface), and TROPOP (diagnostics submodel). In the simulations with MECCA the submodels HETCHEM and PSC were switched on additionally. Note that all simulations were nudged to observed meteorology (ECMWF analysis data).

A side by side comparison of all species contained in the E4CHEM chemical scheme is contained in the supplement and we present only a few examples here. Figure 2 depicts ozone mixing ratios for the zonal average at $30^{\circ} \mathrm{S}-50^{\circ} \mathrm{S}$.
In general, there is good agreement between all simulations. The ozone maximum is located at about $33 \mathrm{~km}$, but is larger by approximately $0.5 \mu \mathrm{mol} / \mathrm{mol}$ in the S-E4CHEM simulation from January to February. Above an altitude of $0.15 \mathrm{hPa}$ S-E4CHEM ozone is lower by about $0.5 \mu \mathrm{mol} / \mathrm{mol}$.

For $\mathrm{NO}_{\mathrm{x}}$, depicted in Fig. 3, a similarly good agreement is obtained. The variation with time and altitude is captured well by S-E4CHEM, with differences only in the mesosphere.

Zonal mean total column ozone is compared as a function of latitude, averaged over the entire year 1998, in Fig. 4. S-E4CHEM (black), S-MECCA(E4CHEM) (red) and S-MECCA(EVAL). Differences are generally less than $2 \%$, only at high latitudes differences are greater with simulation S-MECCA(EVAL) showing the smallest ozone columns. Since the S-MECCA(EVAL) chemical mechanism also incorporates bromine-containing substances, polar ozone loss is stronger in this simulation. Differences in polar ozone between the simulations S-E4CHEM and SMECCA(E4CHEM) are likely due to the differences in the polar stratospheric cloud schemes, as well as in the aerosol surface area assumptions. 

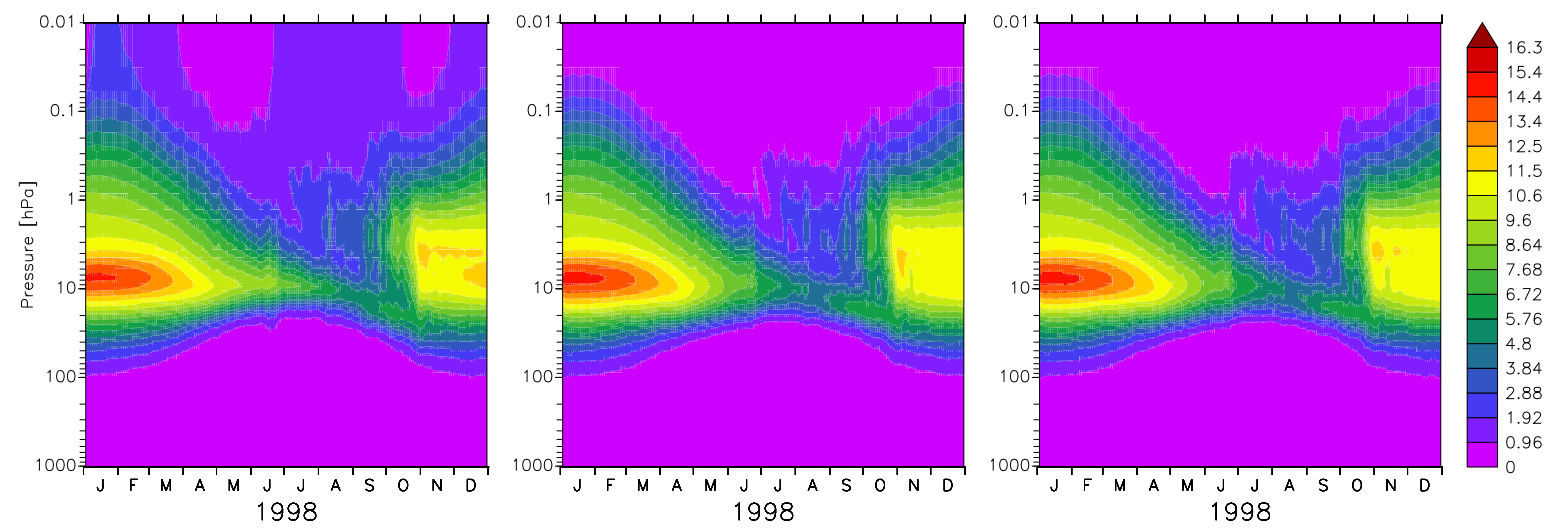

Fig. 3. Same as Fig. 2 but for $\mathrm{NO}_{\mathrm{x}}(\mathrm{nmol} / \mathrm{mol})$ for the zonal average at $60^{\circ} \mathrm{S}-90^{\circ} \mathrm{S}$.

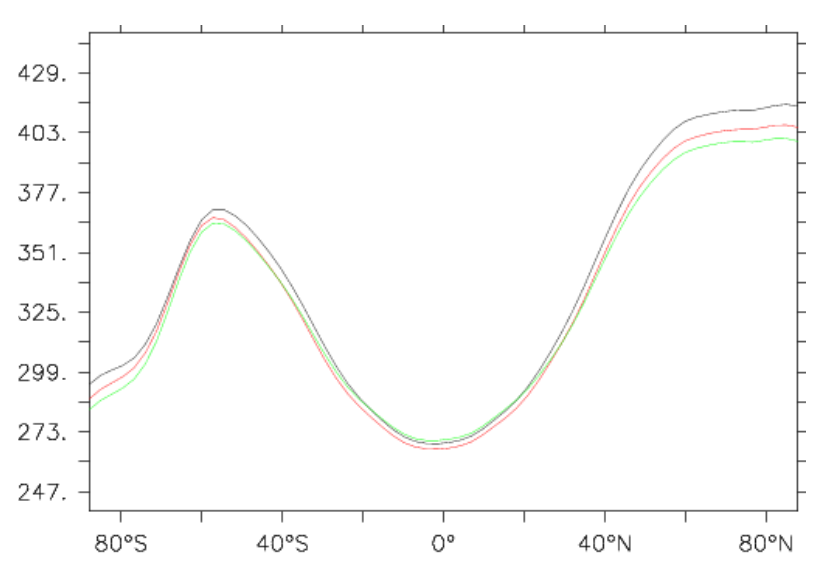

Fig. 4. Zonal and time average (January-December 1998) of total column ozone (DU) for S-E4CHEM (black), S$\operatorname{MECCA}(\mathrm{E} 4 \mathrm{CHEM})$ (red) and S-MECCA(EVAL) (green).

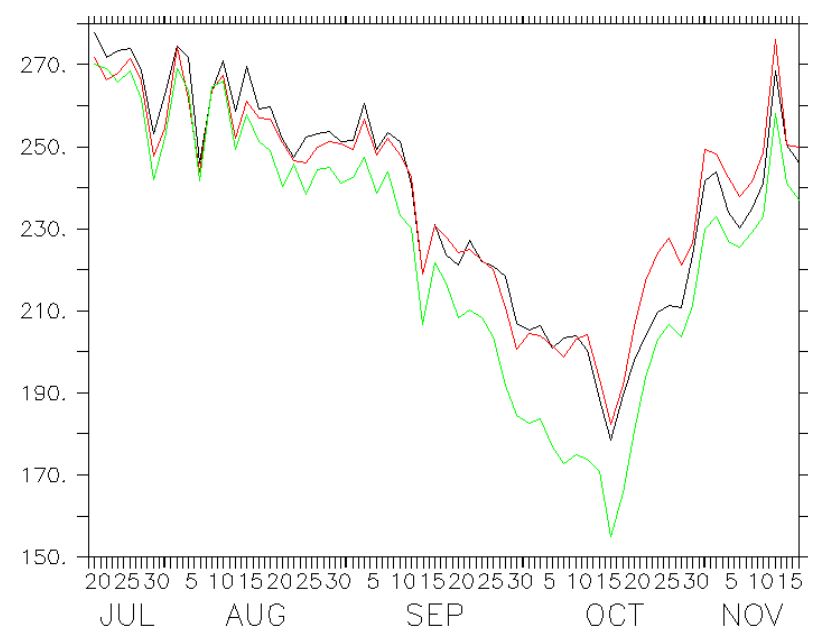

Fig. 5. Minimum total column ozone (DU) for S-E4CHEM (black), S-MECCA(E4CHEM) (red) and S-MECCA(EVAL) (green).
Finally, we compare polar winter ozone loss which is an important atmospheric phenomenon. Minimum total ozone is a commonly used quantity for the diagnostic of the ability of chemistry climate models to reproduce the ozonehole. During the Southern Hemisphere winter 1998, TOMS satellite observations of total column ozone showed a minimum of approximately $100 \mathrm{DU}$ (WMO, 2007). The minimum ozone as a function of time is shown in Fig. 5 for all three simulations. It is evident that there is a strong correlation in minimum ozone between the three simulations due to the very similar dynamics, which is due to the nudging to observed meteorology. Only in September and October minimum ozone in the simulation S-MECCA(EVAL) is significantly lower than in the other two simulations, which, as already mentioned above, is most likely due to the fact that S-MECCA(EVAL) also contains ozone-destroying bromine chemistry.

The computational resource demand of the E4CHEM submodel in comparison to the ECHAM5 basemodel is small. Note that other submodels, but especially the advection routine which has to consider a larger number of species, contribute to a moderate rise in resource demands compared to the hosting basemodel. We measured the consumed CPU time for the simulations presented above, which were performed on an IBM POWER6 computer using 16 nodes with 64 tasks each. The average CPU time consumed by each model time step was $0.47 \mathrm{~s}$ for S-MECCA(E4CHEM) and $0.17 \mathrm{~s}$ for S-E4CHEM, thus the speedup-factor is 2.8 . With respect to the S-MECCA(EVAL) simulation, which required $1.3 \mathrm{~s}$ per time step, the speedup-factors of the SMECCA(E4CHEM) and S-E4CHEM simulations are 2.8 and 7.6, respectively.

\section{Conclusions}

The fast chemical scheme E4CHEM has been implemented as a MESSy submodel. For stratospheric and tropospheric background chemistry applications it serves as an alternative to the flexible MECCA submodel. The main advantage is its 
low computational resource demand compared to MECCA, making it useful for simulations of long timescales. However, including additional species or reactions is complicated and constitutes a major disadvantage.

The E4CHEM submodel has been evaluated in the box model CAABA and the 3-D model EMAC by comparing the results to simulations with MECCA (plus the submodels for heterogeneous chemistry). For the box model, it was shown that the agreement improves clearly if updated reaction rates are used in E4CHEM. Only for some hydrocarbon species significant differences remain, which are due to differences in the hydrocarbon mechanisms. For the most important chemical species such as ozone, water vapour, and nitrogen compounds no disconcerting differences to the simulations with MECCA were found. Due to the very successful use of the chemistry subroutines of E4CHEM in previous implementations in chemistry climate models, we can conclude that the EMAC implementation will be useful for many applications.

Several optional extensions of E4CHEM are planned (B. Steil, personal communication, 2010). An existing extension of CHEM that provides a chemical budget analysis will be implemented in E4CHEM. The chemical mechanism will be extended by bromine containing species, in order to better represent the ozone depletion related to these compounds. Further, NMHC (non-methane hydrocarbon) chemistry might be included for a better representation of the troposphere, and the sulphur cycle could be completed in order to realistically simulate volcanic eruptions. However, these extensions are neither straightforward and their computational efficiency is not yet known.

\section{Supplementary material related to this article is available online at: http://www.geosci-model-dev.net/3/321/2010/ gmd-3-321-2010-supplement.pdf.}

Acknowledgements. This work was funded by the TIES project within the DFG SPP 1176 CAWSES. The Ferret program (http://www.ferret.noaa.gov) from NOAA's Pacific Marine Environmental Laboratory was used for creating some of the graphics in this paper. Thanks go to all MESSy developers and users for their support. The model simulations were performed on the POWER6 computer at the Max Planck Computer Centre in Garching, RZG.

The service charges for this open access publication have been covered by the Max Planck Society.

Edited by: V. Grewe

\section{References}

Austin, J., Shindell, D., Beagley, S. R., Brühl, C., Dameris, M., Manzini, E., Nagashima, T., Newman, P., Pawson, S., Pitari, G., Rozanov, E., Schnadt, C., and Shepherd, T. G.: Uncertainties and assessments of chemistry-climate models of the stratosphere, Atmos. Chem. Phys., 3, 1-27, doi:10.5194/acp-3-1-2003, 2003.

Austin, J., Tourpali, K., Rozanov, E., Akiyoshi, H., Bekki, S., Bodeker, G., Brühl, C., Butchart, N., Chipperfield, M., Deushi, M., Fomichev, V. I., Giorgetta, M. A., Gray, L., Kodera, K., Lott, F., Manzini, E., Marsh, D., Matthes, K., Nagashima, T., Shibata, K., Stolarski, R. S., Struthers, H., and Tian, W.: Coupled chemistry climate model simulations of the solar cycle in ozone and temperature, J. Geophys. Res., 113, D11306, doi: 10.1029/2007JD009391, 2008.

Austin, J., Struthers, H., Scinocca, J., Plummer, D., Akiyoshi, H., Baumgaertner, A. J. G., Bekki, S., Bodeker, G. E., Braesicke, P., Bruehl, C., Butchart, N., Chipperfield, M., Cugnet, D., Dameris, M., Dhomse, S., Frith, S., Garny, H., Gettelman, A., Hardiman, S., Jöckel, P., Kinnison, D., Lamarque, J. F., Marchand, M., Michou, M., Morgenstern, O., Nakamura, T., Nielsen, J. E., Pitari, G., Pyle, J., Shepherd, T. G., Shibata, K., Smale, D., Stolarski, R., Teyssedre, H., and Yamashita, Y.: Chemistry climate model simulations of the Antarctic ozone hole, J. Geophys. Res., in press, doi:10.1029/2009JD013577, 2010.

Dameris, M., Grewe, V., Ponater, M., Deckert, R., Eyring, V., Mager, F., Matthes, S., Schnadt, C., Stenke, A., Steil, B., Brühl, C., and Giorgetta, M. A.: Long-term changes and variability in a transient simulation with a chemistry-climate model employing realistic forcing, Atmos. Chem. Phys., 5, 2121-2145, doi:10.5194/acp-5-2121-2005, 2005.

Eyring, V., Butchart, N., Waugh, D. W., Akiyoshi, H., Austin, J., Bekki, S., Bodeker, G. E., Boville, B. A., Brühl, C., Chipperfield, M. P., Cordero, E., Dameris, M., Deushi, M., Fioletov, V. E., Frith, S. M., Garcia, R. R., Gettelman, A., Giorgetta, M. A., Grewe, V., Jourdain, L., Kinnison, D. E., Mancini, E., Manzini, E., Marchand, M., Marsh, D. R., Nagashima, T., Newman, P. A., Nielsen, J. E., Pawson, S., Pitari, G., Plummer, D. A., Rozanov, E., Schraner, M., Shepherd, T. G., Shibata, K., Stolarski, R. S., Struthers, H., Tian, W., and Yoshiki, M.: Assessment of temperature, trace species, and ozone in chemistry-climate model simulations of the recent past, J. Geophys. Res., 111, D22308, doi:10.1029/2006JD007327, 2006.

Eyring, V., Waugh, D. W., Bodeker, G. E., Cordero, E., Akiyoshi, H., Austin, J., Beagley, S. R., Boville, B. A., Braesicke, P., Brühl, C., Butchart, N., Chipperfield, M. P., Dameris, M., Deckert, R., Deushi, M., Frith, S. M., Garcia, R. R., Gettelman, A., Giorgetta, M. A., Kinnison, D. E., Mancini, E., Manzini, E., Marsh, D. R., Matthes, S., Nagashima, T., Newman, P. A., Nielsen, J. E., Pawson, S., Pitari, G., Plummer, D. A., Rozanov, E., Schraner, M., Scinocca, J. F., Semeniuk, K., Shepherd, T. G., Shibata, K., Steil, B., Stolarski, R. S., Tian, W., and Yoshiki, M.: Multimodel projections of stratospheric ozone in the 21 st century, J. Geophys. Res., 112, D16303, doi:10.1029/2006JD008332, 2007.

Eyring, V., Shepherd, T. G., and Waugh, D. W. (Eds.): SPARC CCMVal Report on the Evaluation of Chemistry-Climate Models, SPARC Report No. 5, WCRP-X, WMO/TD-No. X, 2010.

Grewe, V.: Impact of climate variability on tropospheric ozone, Sci. Total Environ., 374, 167-181, 2007. 
Hanson, D. and Mauersberger, K.: Laboratory studies of the nitric acid trihydrate - Implications for the south polar stratosphere, Geophys. Res. Lett., 15, 855-858, doi:10.1029/ GL015i008p00855, 1988.

Hein, R., Dameris, M., Schnadt, C., Land, C., Grewe, V., Köhler, I., Ponater, M., Sausen, R., B. Steil, B., Landgraf, J., and Brühl, C.: Results of an interactively coupled atmospheric chemistry general circulation model: Comparison with observations, Ann. Geophys., 19, 435-457, doi:10.5194/angeo-19-435-2001, 2001.

Jöckel, P., Sander, R., Kerkweg, A., Tost, H., and Lelieveld, J.: Technical Note: The Modular Earth Submodel System (MESSy) - a new approach towards Earth System Modeling, Atmos. Chem. Phys., 5, 433-444, doi:10.5194/acp-5-433-2005, 2005.

Jöckel, P., Tost, H., Pozzer, A., Brühl, C., Buchholz, J., Ganzeveld, L., Hoor, P., Kerkweg, A., Lawrence, M. G., Sander, R., Steil, B., Stiller, G., Tanarhte, M., Taraborrelli, D., van Aardenne, J., and Lelieveld, J.: The atmospheric chemistry general circulation model ECHAM5/MESSy1: consistent simulation of ozone from the surface to the mesosphere, Atmos. Chem. Phys., 6, 50675104, doi:10.5194/acp-6-5067-2006, 2006.

Jöckel, P., Kerkweg, A., Buchholz-Dietsch, J., Tost, H., Sander, R., and Pozzer, A.: Technical Note: Coupling of chemical processes with the Modular Earth Submodel System (MESSy) submodel TRACER, Atmos. Chem. Phys., 8, 1677-1687, doi:10.5194/acp8-1677-2008, 2008.

Kerkweg, A., Buchholz, J., Ganzeveld, L., Pozzer, A., Tost, H., and Jöckel, P.: Technical Note: An implementation of the dry removal processes DRY DEPosition and SEDImentation in the Modular Earth Submodel System (MESSy), Atmos. Chem. Phys., 6, 4617-4632, doi:10.5194/acp-6-4617-2006, 2006a.

Kerkweg, A., Sander, R., Tost, H., and Jöckel, P.: Technical note: Implementation of prescribed (OFFLEM), calculated (ONLEM), and pseudo-emissions (TNUDGE) of chemical species in the Modular Earth Submodel System (MESSy), Atmos. Chem. Phys., 6, 3603-3609, doi:10.5194/acp-6-3603-2006, 2006b.

Landgraf, J. and Crutzen, P. J.: An Efficient Method for Online Calculations of Photolysis and Heating Rates, J. Atmos. Sci., 55, 863-878, doi:10.1175/1520-0469(1998)055, 1998.

Lemmen, C., Dameris, M., Müller, R., and Riese, M.: Chemical ozone loss in a chemistry-climate model from 1960 to 1999 , Geophys. Res. Lett., 33, L15820, doi:10.1029/2006GL026939, 2006.

Manzini, E., Steil, B., Brühl, C., Giorgetta, M. A., and Krüger, K.: A new interactive chemistry-climate model: 2. Sensitivity of the middle atmosphere to ozone depletion and increase in greenhouse gases and implications for recent stratospheric cooling, J. Geophys. Res., 108(D14), 4429, doi:10.1029/2002JD002977, 2003.
Riede, H., Jöckel, P., and Sander, R.: Quantifying atmospheric transport, chemistry, and mixing using a new trajectory-box model and a global atmospheric-chemistry GCM, Geosci. Model Dev., 2, 267-280, doi:10.5194/gmd-2-267-2009, 2009.

Sander, R., Kerkweg, A., Jöckel, P., and Lelieveld, J.: Technical note: The new comprehensive atmospheric chemistry module MECCA, Atmos. Chem. Phys., 5, 445-450, doi:10.5194/acp-5445-2005, 2005.

Sander, R., Baumgaertner, A. J. G., Gromov, S., Harder, H., Jöckel, P., Kerkweg, A., Kubistin, D., Riede, H., Taraborrelli, D., and Tost, H.: The atmospheric chemistry box model CAABA/MECCA-3.0, Geosci. Model Dev., in preparation, 2010.

Sandu, A. and Sander, R.: Technical note: Simulating chemical systems in Fortran90 and Matlab with the Kinetic PreProcessor KPP-2.1, Atmos. Chem. Phys., 6, 187-195, doi:10.5194/acp-6187-2006, 2006.

Steil, B.: Modellierung der Chemie der Strato- und Troposphäre mit einem drei-dimensionalen Zirkulationsmodell, $\mathrm{Ph} . \mathrm{D}$. thesis, Institut für Meteorologie, Universität Hamburg, 1997.

Steil, B., Dameris, M., Brühl, C., Crutzen, P. J., Grewe, V., Ponater, M., and Sausen, R.: Development of a chemistry module for GCMs: first results of a multiannual integration, Ann. Geophys., 16, 205-228, doi:10.1007/s00585-998-0205-8, 1998.

Steil, B., Brühl, C., Manzini, E., Crutzen, P. J., Lelieveld, J., Rasch, P. J., Roeckner, E., and Krüger, K.: A new interactive chemistryclimate model: 1 . Present-day climatology and interannual variability of the middle atmosphere using the model and 9 years of HALOE/UARS data, J. Geophys. Res., 108(D9), 4290, doi: 10.1029/2002JD002971, 2003.

Stenke, A., Dameris, M., Grewe, V., and Garny, H.: Implications of Lagrangian transport for simulations with a coupled chemistry-climate model, Atmos. Chem. Phys., 9, 5489-5504, doi:10.5194/acp-9-5489-2009, 2009.

Tost, H., Jöckel, P., Kerkweg, A., Sander, R., and Lelieveld, J.: Technical note: A new comprehensive SCAVenging submodel for global atmospheric chemistry modelling, Atmos. Chem. Phys., 6, 565-574, doi:10.5194/acp-6-565-2006, 2006 a.

Tost, H., Jöckel, P., and Lelieveld, J.: Influence of different convection parameterisations in a GCM, Atmos. Chem. Phys., 6, 54755493, 2006b.

Tost, H., Jöckel, P., and Lelieveld, J.: Lightning and convection parameterisations - uncertainties in global modelling, Atmos. Chem. Phys., 7, 4553-4568, doi:10.5194/acp-7-4553-2007, 2007.

WMO (World Meteorological Organization): Scientific Assessment of Ozone Depletion: 2006, Global Ozone Research and Monitoring Project - Report No. 50, 572 pp., Geneva, Switzerland, 2007. 